\title{
Ecology and Use of Lantana camara in India
}

\author{
Girish C. S. Negi ${ }^{1,2} \cdot$ Subrat Sharma $^{1} \cdot$ Subash C.R. Vishvakarma ${ }^{1}$ • \\ Sher S. Samant ${ }^{1} \cdot$ Rakesh K. Maikhuri $^{1} \cdot$ Ram C. Prasad $^{1} \cdot$ Lok M. S. Palni $^{1}$ \\ ${ }^{1}$ G.B. Pant National Institute of Himalayan Environment \& Sustainable Development, Kosi-Katarmal, \\ Almora, Uttarakhand 263 643, India \\ ${ }^{2}$ Author for Correspondence; e-mail: negigcs@gmail.com \\ Published online: 6 May 2019 \\ (C) The Author(s) 2019
}

\begin{abstract}
In the Indian sub-continent Lantana has invaded vast tracts of dry-moist forests and other culturable wastelands, and has potentially altered biodiversity, landscape ecology and ecosystem services. It has invaded most Indian pasture lands (13.2 million ha) besides forest and fallow areas, and the cost of its control is estimated at US\$ 70 per ha. This invasive weed stands out because of its rapid spread, intensity of infestation, allelopathy, opportunistic growth behaviour, reproductive biology traits and tenacious resistance to cutting and burning. This paper reviews the current knowledge on L. camara with particular focus on its ecological attributes such as biomass productivity, reproductive biology, invasiveness, allelopathy, eradication measures and economic uses reported from India. Based on the literature review it can be pointed out that the positive impacts and economic uses of Lantana outweigh its negative impacts and require further studies on cost-benefit considerations for decision making for its eradication and management.
\end{abstract}

Keywords Lantana camara · Ecology · Invasion · Eradication, Positive and Negative impacts, India

\section{Introduction}

Lantana is a genus (family Verbenaceae) of about 150 species of herbs, under shrubs and shrubs growing to $0.5-2 \mathrm{~m}$ tall. The genus Lantana, as described by Linnaeus in 1753 in Species Plantarum contains seven species, six from South America and one from Ethiopia (Munir, 1996). Lantana is mostly native to subtropical and tropical America, but a few taxa are indigenous to tropical Asia and Africa. It now occurs in approximately 50 countries where several species are cultivated for its flowers under hundreds of cultivar names. The recorded number of Lantana species varies from 50 to 270 specific and sub-specific entities, but it appears that a better estimate is 150 species (Munir, 1996). The genus is a difficult one to classify taxonomically since species are not stable and hybridization is widespread, shape of inflorescence changes with age, and flower colours vary with age and maturity (Munir, 1996). L. camara L., commonly 
known as wild or red sage, is the most widespread species of this genus, growing luxuriantly at elevations up to $1800 \mathrm{~m}$ asl. in tropical, sub-tropical and temperate regions (Parsons, 1992). The plant is native to tropical regions of the America and Africa (Nayar, 1977). However, as an introduced species they are found in various localities of the globe especially in the Australian-Pacific region. Dutch explorers introduced Lantana into the Netherlands from Brazil in the late 1600s and later explored from tropical, sub-tropical and temperate regions (Sharma et al., 1988). In the 18th and nineteenth century, nurserymen commercialized and popularized many colourful forms of Lantana, and it is now cultivated world-wide as an ornamental plant. Of the 650 cultivar names in the genus, the majority are associated with the L. camara complex. L. camara has been cultivated for its flowers over 300 years and now has hundred of cultivars and hybrids and distinguished morphologically, physiologically and genetically (Binggeli, 1999).

\section{Lantana Introduction in India}

L. camara var. aculeata Moldenke known as Lantana wild sage is a low, erect or subscandent woody perennial shrub (0.3-1.8 m or more in height) with stout recurved prickles and a strong odour of black currants. In India seven or eight species such as L. camara, L. indica, L. veronicifoila and L. trifolia have been reported, besides species of horticultural value (Rajendran \& Daniel, 2002). Three varieties of $L$. camara have been reported from India. These are L. camara var. aculeata Moldenke, L. camara var. mista Bailey and L. camara var. nivea Bailey. Amongst these L. camara var. aculeata is the most common. Numerous varieties and types of L. camara are found; some of them are polyploids. L. camara is of hybrid origin and is a polyploid complex. In India it is composed of polyploids ranging from $2 x$ to $7 x(x=11)$ (Kumar \& Subramaniam, 1986). There is a marked variability in morphological features such as habit, thorniness, and characteristics of leaf, flower and inflorescence, and size of fruits among different populations of $L$. camara. The varieties and types are very difficult to differentiate on the basis of morphological features. Most of them have recurved prickles on the stem. But under cultivation they become less prickly or even unarmed, less vigorous in growth, and they set seeds less freely. Dwarf types have been developed for growing in hanging baskets and as a hedge along borders of houses.

Lantana was initially brought to India in 1807 as an ornamental plant at the National Botanical Garden (Kohli et al., 2006), and as an ornamental hedge plant in Calcutta in the early nineteenth century (Hakimuddin, 1929). But later this plant has spread out across all open areas along road sides, railway tracks, edges of crop fields and open forests all over the country. Now, it has become completely naturalized and found throughout India (https://en.wikipedia.org/wiki/Lantana_camara). In North West Himalayan region, L. camara was introduced during 1905 in Kathgodam, district Nainital (Hakimuddin, 1929; Hiremath \& Sundaram, 2005). It has invaded about 13.2 million ha in Indian pasture lands besides forest and fallow areas. L. camara is widely distributed in the tropical and sub-tropical zones including the protected forest areas of India. In some places, it has also entered in the temperate zones (Kimothi et al., 2010). In the Garhwal Himalaya (north India) also, two species viz., Lantana camara and L. indica have been found growing profusely in all habitats of submontane and montane zone up to $2000 \mathrm{~m}$ altitude (Dobhal et al. 2010; Bisht et al., 2012). It is widely 
distributed in the tropical and sub-tropical forests and mainly associated with Acacia catechu, Dalbergia sissoo, Pinus roxburghii, Shorea robusta, Tectona grandis and other evergreen and miscellaneous forests. Niche models have predicted its potential distribution almost throughout India (Ray \& Ray, 2014).

\section{Ecological Fitness}

The diverse and broad geographic distribution of Lantana is a reflection of its wide ecological tolerance. It occurs in diverse climate, habitats and on a variety of soil types. It generally grows best in open unshaded situations such as wastelands, rainforest edges, beachfronts, and forests recovering from fire or logging. Disturbed areas such as beside roads, railway tracks and canals are also favourable habitats for this species (Thakur et al., 1992; Munir, 1996). The plant is found at altitudes from sea level to 1800 masl and can thrive very well under rainfall ranging from 750 to $5000 \mathrm{~mm}$ per annum. It grows in rich as well as poor soils, including gravel and laterite and low lying areas and on hills up to $1800 \mathrm{~m}$ asl. It is drought resistant, light loving and tolerates moderate shade. It does not grow at ambient temperatures below $5{ }^{\circ} \mathrm{C}$. Lantana does not invade intact forests, but encroaches where natural forests have been disturbed through logging creating gaps. It cannot survive under dense, intact canopies of taller native forest species. The plant is susceptible to frosts and low temperatures, saline soils, boggy or hydromorphic soils, low rainfall, coralline soils with poor water-holding capacity (http://www.fao.org/forestry). It spreads rapidly through root suckers and profuse seeding every year and is toxic to ruminants (Sharma et al., 1988). In the $L$. camara shurblands of western Himalayan mountains, Bhatt (1990) found soil water holding capacity $($ range $=37.6-45.3 \%)$, soil moisture $(14.4-19.6 \%), \mathrm{pH}(6-6.5)$, total nitrogen $(0.07 \%-0.12 \%)$ and phosphorus $(0.001-0.005 \%)$ across soil depth of $0-5 \mathrm{~cm}$ to $15-20 \mathrm{~cm}$, respectively. Sites occupied by L. camara are found relatively rich in nutrients compared to sites without $L$. camara thus further facilitate invasion of this species (Manda \& Joshi, 2015).

\section{Reproductive Biology}

Phenology of L. camara has been studied in detail in the Central Himalayan foothills of India (Bhatt, 1990). In this region, L. camara starts vegetative bud production in the last week of March that peaks in mid-April and leafing continues till mid-August with leaf longevity of about 267 days. The mature leaf weighs about $226 \mathrm{mg}$ and leaf area at fullest expansion measures about $18 \mathrm{~cm}^{2}$ (Bhatt, 1990). Leaf senescence starts in early December and by the end of February Lantana bushes become leafless. A rapid shoot growth (up to $20 \mathrm{~cm}$ per year), lengthy leafing period (5-6 months) and display of flowers and fruits during most of the growing period are some phenological traits, which indicate the tropical affinity of this shrub (Shimizu, 1983). This opportunistic growth pattern results in producing a considerable proportion of foliage and reproductive parts, which enables $L$. camara to exploit the ecological niche optimally during the warm and wet rainy season (Negi, 1989).

Aromatic flower clusters of Lantana, called umbels are a mix of red, orange, yellow, or blue and white flowers. The flowers typically change colour as they mature, resulting 
in inflorescence that are two-three coloured. A common name for L. camara is "Ham'n Eggs" due to the adjacent pink and yellow inflorescences. L. camara flowers are small, 5 lobed, in flat rounded heads about $5 \mathrm{~cm}$ across, in dense umbel- like aggregations that are brightly bicoloured, tubular and sweet smelling. Flowers usually occur all year round, but are most prolific during wet summer months with one more flowering episode in mid-October. It takes about two weeks for fruiting after flowering, and ripened fruits can be found in the bushes till mid-December. Thus the mature flowers and fruits are available in the L. camara bushes for 4-5 months and present enough opportunity to pollinators and seed dispersal agents that helps in its proliferation. L. camara is primarily pollinated by butterflies (Schemske, 1976) or thrips, as well as sunbirds (in India) and hummingbirds (in Brazil) in some cases resulting in $85 \%$ fruit set (Hilje, 1985). Butterflies are the most frequent pollinators of L. camara, as they constitute $62 \%$ of the total visitors. Bees, wasps, moths and other insect groups also visit L. camara flowers, but are less frequent pollinators (http://easternarc.or. tz/downloads/TBA-East-Usambara/reports-2005). Kugler (1980) reported that over $38 \%$ of insect visitors on flowers were Bombus hortorum, nearly $20 \%$ were Xylocopa violaceae, 9\% Amegilla quadrifasciata and 6\% Apis mellifera. Pollination in L. camara consists of both self and cross-pollination. There are conflicting reports over the plant's ability to self-pollinate (http://www.tropical-biology.org/ research/dip/species/Lantana. $\mathrm{htm})$. Since, nearly all cultivars of $L$. camara are self-compatible and are generally pollinated by thrips, mere observation and visual inspection of the flowers should give a good indication of their fecundity. Flower colour changes from yellow to pink after pollination, hence multiple colours in a single inflorescence are found, thus increases the optical attractiveness of the inflorescence that provide rewards for pollinators. The flowers are adapted to butterfly pollination (psychophilous flowers), open throughout the day with shorter tubes or spurs that provide a landing platform for the butterflies.

Large quantities of small greenish blue-black globose fruits of about $5 \mathrm{~mm}$ diameter are produced mostly during monsoon season. Fruits are hard and green when unripe, turning fleshy and purplish-black when ripe. The fruits have a single stony seed (Stone, 1970). The seed has two embryos, but germination of both happens only rarely. Germination of L. camara seeds is low (4 - 45\%) due to seed dormancy, low seed viability, and meiotic instability (Duggin \& Gentle, 1998; Sahu \& Panda, 1998), low seedling mortality and fast vegetative spread compensate for this deficit (Sahu \& Panda, 1998). Seed germination in L. camara is known to be stimulated by warm temperatures, exposure to light, and high soil moisture. When sown under thin cover at $20{ }^{\circ} \mathrm{C}$ in light, seed germinates in about two weeks. It re-sprouts readily on being burnt and it flowers and fruits year round, producing copious quantities of seeds (Hakimuddin, 1929). Fruit dispersal is mostly through frugivorous birds (often the Mynah bird); also sometimes by goats, sheep, cattle, monkeys, fox and rodents.

L. camara also reproduces and disperses vegetatively very easily. Germination rate of fresh seed is generally low, but the germinability gets improved when the seed passes through the digestive system of birds and animals (https://www.facebook. com/permalink.php?story_fbid). Therefore, such information regarding the behaviour and feeding preferences of birds on Lantana fruits may prove useful in terms of integrated control or selecting new agents. Also, birds tend not to eat fruits damaged by the seedfly Ophiomyia lantanae, so the impact of flower-feeding and seed-feeding insects on Lantana and the insect population levels that are needed to significantly 
reduce seed set or damage seed needs to be studied (Day et al., 2003). High light intensity and soil temperature stimulates germination of seeds, which means that clearing of forest areas, inappropriate burning and other disturbances will help spread of the weed. Seeds are capable of surviving the hottest fires (http://www.fao. org/forestry/13375-.pdf). Its growth is stimulated by disturbances such as mild fire, cutting, pruning, and grazing. Raizada and Raghubanshi (2010) reported that smoked seeds germinate earlier than non-smoked seeds; hence fire could enhance seed germination in L. camara. Further, seedling mortality was found lower in the case of smoked seeds. Also, little is known about Lantana's soil seed-bank dynamics. Anecdotal evidence suggests that seeds remain viable in the soil for about two years, but apparently no formal studies have been made that would assist in control and to know how long follow-up treatments would need to be implemented following the removal of Lantana by conventional means.

\section{Biomass and Productivity}

In the Himalayan foothills in north India the aboveground biomass of $L$. camara across shoot diameter $(0.6-3.5 \mathrm{~cm})$ classes was reported to be $2.15-33.4 \mathrm{~T} \mathrm{ha}^{-1}$, and that of Lantana shrubland community (that also consists of other shrubs and herbs) 6.34 to $43.29 \mathrm{~T} \mathrm{ha}^{-1}$, of this $85.8 \%$ was accounted for by aboveground parts and $14.2 \%$ by belowground parts (Bhatt, 1990). To the total shrub biomass of bushland vegetation, L. camara contributed 78\%, other shrubs (19.5\%) and herbs (2.5\%) (Adhikari et al., 2009). Further, the seeds and reproductive parts accounted for a measurable portion $(3.40 \%)$ of the biomass, showing its ruderal strategy. The net primary production of L. camara alone was $13.7 \mathrm{~T} \mathrm{ha}^{-1}$ (aboveground 10.7 and belowground $3.0 \mathrm{~T} \mathrm{ha}^{-1} \mathrm{yr}^{-1}$ ), of which shoot contributed $50 \%$, followed by foliage $(25 \%)$, roots $(22 \%)$ and reproductive parts $(1.5 \%)$, which is six to fourteen-fold higher than that reported for the shrub layers in the natural forest communities of the Central Himalaya, India (Chaturvedi, 1983; Rawat \& Singh, 1988; Rana et al., 1989). The net primary productivity of Lantana was comparable to about 10-28 $\mathrm{T} \mathrm{ha}^{-1} \mathrm{yr}^{-1}$ for the sub-tropical and temperate forests (Singh \& Singh, 1987). Vasudevan and Jain (1991) have reported that Lantana contains about $70-80 \%$ of woody biomass with annual production rate of 40 $60 \mathrm{~T} \mathrm{ha}^{-1} \mathrm{yr}^{-1}$. In western Ghats (Tamilnadu, India) greater biomass of L. camara was recorded among many herbaceous communities that could be attributed to high degree of disturbance and open environment (Chandrasekaran \& Swamy, 2002). Thus, L. camara productivity compares well with the potential forest communities, particularly in the degraded lands with nutrient poor soil.

\section{Litterfall and Nutrients}

Total annual litter fall (leaf + wood + reproductive parts) in L camara is reported $3.82 \mathrm{~T} \mathrm{ha}^{-1} \mathrm{yr}^{-1}, 80 \%$ of it occurs during November to February in the Himalayan foothills in north India (Bhatt, 1990). Lantana leaves decompose completely in about 13-14 months (Negi \& Kandpal, 2003) and contain high concentration of nutrients in leaves $(N=1.71 \%$ and $P=0.09 \%)$. The total quantity of nitrogen contained in L. camara biomass was recorded $289.7 \mathrm{Kg} \mathrm{ha}^{-1}$, and phosphorus $\left(16 \mathrm{~kg} \mathrm{ha}^{-1}\right)$, and the total $\mathrm{N}$ and $\mathrm{P}$ returned via litterfall was 57.3 and $3.1 \mathrm{~kg} \mathrm{ha}^{-1} \mathrm{yr}^{-1}$, respectively, 
which is comparable to the mature climax forests of the sub-tropical and temperate climate of India (Singh, 1992). L. camara has greater influence on the functioning of the shrub community in terms of nutrient cycling with high quantity of $\mathrm{N}$ retranslocation from senescing leaves $\left(73 \mathrm{~kg} \mathrm{ha}^{-1} \mathrm{yr}^{-1}\right)$ and high $\mathrm{N}$ concentration in leaf litter that may help it in outcompeting other species. High productivity of L. camara on degraded land with poor soil fertility may be related to high nutrient extraction efficiency, which is the extraction of nutrients in net primary productivity relative to nutrients in soil and higher retranslocation of nutrients from the foliage (Singh, 1992). Sharma and Raghubanshi (http://www.designsystems. in/currentconservation) observed that high $\mathrm{N}$ and low lignin content of Lantana litter and the favorable microclimate beneath Lantana canopies favour faster decomposition and release of $\mathrm{N}$ leading to increase in soil $\mathrm{N}$ availability, $\mathrm{N}$ mineralization, and total soil $\mathrm{N}$, leading to a positive feedback, and this, in turn, favours the growth of Lantana.

\section{Negative Impacts on Ecosystems}

\section{Invasion by $L$. camara}

Invasive plants are commonly recognized to have severe ecological impacts in a wide range of ecosystems throughout the world. They can alter ecosystem structure and function, trophic structure, resource availability and downgrade biodiversity of natural landscapes. Lantana camara is one such invasive alien species and considered by IUCN as one of the world's 100 most invasive species, and among the world's 10 worst weeds. Invasion by non-native exotic plant species poses a serious threat to native plant communities and ecosystem properties, such as population dynamics and community structure (Mooney \& Drake, 1986; Pimentel et al., 2001), and alters native vegetation and causes threat to biodiversity (Vitousek et al., 1996; Mack et al., 2000). Habitat disturbance due to anthropogenic or environmental reasons (Heywood, 1989) modifies the microclimate, resulting in colonizing the invading species such as Lantana, particularly in dry deciduous environment (Heirro \& Callaway, 2003). Some species of Lantana are invasive, and are considered to be noxious weeds, such as in Indian Subcontinent, Southern Africa and Australia. The plant is an aggressive, obligate out breeder weed that has invaded vast expanses of pastures, orchards and forest areas in many tropical and subtropical regions. Lantana has invaded most Indian pasture lands (13.2 million ha) besides forest and fallow areas, and the cost of its control is estimated to be US\$ 70 per ha (Sharma \& Raghubanshi; http://www.designsystems.in/ currentconservation). The lantana-infested landscapes not only are impoverished as habitats of wildlife but also contribute to human-wildlife conflicts owing to diminished ecosystem services. In the Himalayan foothills thick Lantana bushland provide shelter to wild Boar causing damage to crops that also poses hazards of attack to the local people (Singh and Singh, 1987).

India has witnessed negative impact on forest ecosystems posed by invasive species such as Ageratum conyzoides, Eupatorium sp., Lantana camara, Mikania micrantha and Parthenium hysteophorus (Ramakrishnan, 1991; Saxena, 1991; Kohli et al., 2006). Among them, L. camara is one of the most serious invasive plant species and has colonized large areas of forests in the Himalayan foothills both in open and protected 
areas such as Dudhwa, Corbett and Rajaji National Parks in India. Nearly $18 \%$ of the Indian flora is constituted by adventives aliens of whom 55\% are American (Nayar, 1977). There are, however, no recent data regarding the exact number and incidence of these introduced invasive species in India (Love et al., 2009). Lantana has very vigorously invaded forest areas, which have been under high anthropogenic disturbances such as grazing and deforestation (Joshi, 2002; Love et al., 2009). In Indian conditions it is found nearly in all forest types in tropics and sub-tropics and make highly dense pockets $(1500-3000$ plants/ha), and height ranging from $1.5-3.0 \mathrm{~m}$ (Joshi, 2002). Due to its prolific growth and wide adaptability, Lantana has over run large area in India and has developed into a serious pest. Infested areas include cultivable and waste lands, forest areas, grazing and pasture lands and some plantations. The areas worst affected are parts of Deccan and portion of Coorg, Wynaad, Nilgiris and lower hills of Western Ghats. It has also invaded parts of Uttar Pradesh and tropical and sub-tropical zones of the Indian Himalayan region including parts of the North Eastern States.

In the foothills of Nainital district in north India, till 1911 Lantana was sparsely distributed and remained confined to hedges (Hakimuddin, 1929), and did not occur more than a few miles from its place of introduction. Within two decades, however, it has spread in a thick continuous mass to a distance of about 25 miles in all directions, indiscriminately taking over farms and pastures, fallow land and forests. Now after a century, this invasive species is a major ecological problem in Garhwal (Rajwar, 2007), and Kumaun hills of Uttarakhand (Bhatt, 1990), and this shrub is now truly native in this region. Jim Corbett (1944) in his book "Man-eaters of Kumaon" has observed the thickets of Lantana bushes as hiding shelters of leopard in foothills of Kumaon. It has become a menace and forms pure stands in protected areas. As a result of the removal of tree cover and continued grazing in the south facing landscapes in the tarai foothills, shivalik and mid-montane belt of north India, this light demanding species has successfully established. It has especially expanded along roads, footpaths and in lands around human settlements. Singh and Singh (1987) reported that much of the degraded slopes resulting from the deforestation and erosion, overgrazed lands and abandoned crop fields are heavily colonized by Lantana. Copious seed production and their efficient dispersal by birds make $L$. camara particularly invasive. The bush patch expands with the help of strong root system (Troup, 1921). In the Central Himalayan region this bush has assumed a permanent feature of the landscape and represents a kind of converted ecosystem and influences the landscape ecology of this region (Dobhal et al., 2010). In the Pinus roxburghii forests in Kumaun hills in India, L. camara (Importance Value Index $=91.0 \&$ basal area $=1.1 \mathrm{~m}^{2} \mathrm{ha}^{-1}$ ) was found dominant in the shrub layer (Bhatt et al., 1994; Rawat et al., 1994). In the Garhwal hills in India native shrubs such as, Adhatoda vasica, Carissa opaca, Justicia adhatoda, Rubus biflorus, Murraya koenigii, Nyctanthes abortristis etc. are being out competed by Lantana invasion (Sharma and Kumar, 2009). In lower Himalayas, Sharma and Raghubanshi (2009) reported that invasion and proliferation of L. camara causing a change in vegetation and drastic reduction in the grass biomass foraged by livestock. L. camara has been also reported to invade Pine (P. roxburghii) forests also in Pakistan (Siddiqui et al., 1995). In tropical dry forests of India many species exhibit declining or even severely depleted populations in Lantana-invaded locations (Raghubanshi \& Tripathi, 2009). Examples of species with declining populations include Acacia 
auriculiformis, Adina cordifolia, Boswellia serrata, Briedelia retusa, Buchanania lanzan, Cassia fistula, Elaeodendron glaucum, Emblica officinalis, Eriolena quinquelaris, Hardwickia binata, Miliusa tomentosa, Schrebera swietenioides etc.). Such invasions create demographic instability among native tree species, reduce tree diversity, and could even change the structure of the forest in the near future. In India and elsewhere Lantana undergrowth in Teak plantations has affected the growth of Teak plants, reducing the basal area increment by 33\%. In the Garhwal hills in north India in the Lantana and Eupatorium infested habitats, specific decline in the populations of birds was recorded which feed on the ground (e.g., pheasants, partridges, doves, tree pie, thrushes, pipits, etc.), on insects (drongos, bush chats, tits, flycatchers, bee eaters), and on nectar, like sun birds (Bisht et al., 2012). It can be pointed out that the invasive species does not allow growth of suitable food material to the ground feeding birds, which had a very common appearance in this region earlier when there was least infestation of weeds. Also, phototoxic substances released by the Lantana roots damage the soil organisms and repel the insect fauna which constitute the diet of many bird species (Bisht \& Dobriyal, 2002). Thus Lantana invasion is also harmful to the avifaunal diversity. In some areas, Lantana harbours injurious insect pests, including malarial mosquitoes (CSIR,1962).

\section{Lantana and Fire}

Lantana has several characters that invites fire (Hiremath \& Sundaram, 2005). It resprouts readily on being burnt (Pereira, 1919; Hakimuddin, 1929). The fire has favourable effect on the growth of Lantana. This not only increases coppicing potential of the species but also breaks the dormancy of the seeds and helps in massive new growth. Lantana affected with fire regenerate more vigorously than control (Joshi, 2002). Similarly, seeds exposed to surface fire have shown early sprouting than the seeds not exposed. Studies from other parts of the tropics confirm that Lantana may be favoured by disturbances such as fire and grazing (Duggin and Gentle, 1998; Gentle \& Duggin, 1997). Climbing stems of Lantana can reach up to $>20 \mathrm{~m}$, getting into the forest canopy and resulting in crown fires when they burn (Tireman, 1916). Lantana has thus many adverse effects on forest ecosystems which include (i) loss of native biodiversity (Sharma et al., 2005; Day et al., 2003); (ii) replacing native plant communities in forests by forming dense impenetrable thickets, (iii) contributing to soil erosion (Day et al., 2003, FAO: http://www.fao.org/forestry/media), (iv) hampering regeneration of forests (Sharma et al., 2005; Day et al., 2003), (v) harbouring vectors that carry infectious diseases (Syed \& Guerin, 2004) and (vi) promoting fire hazard (Hiremath \& Sundaram, 2005).

\section{Allelopathic Effect}

Allelopathy is a phenomenon in which chemicals released by the invasive plant discourage growth of native plants (Heirro \& Callaway, 2003). It represents the plant-plant interactions, a part of chemical ecology. The success of Lantana in different environmental conditions could also be due to its allelopathic effect on other plants. Lantana disrupts succession, decreases biodiversity, and can reduce vigour of native plants due to allelopathy (Day et al., 2003; Holm et al., 1979). Impact of L. camara 
allelopathy is not universal, it may vary from crop to crop. Maiti et al. (2008) reported that the leaf extracts and leachates of Lantana reduce germination, speed of germination, seed viability and seedling emergence capacity of Mimosa seeds. The effect of L. camara aqueous leaf extracts of different concentrations shows significant inhibitory effect on germination, root and shoot elongation and development of lateral roots of food crops such as Brassica juncea, Cicer arietinum, Cucumis sativus, Phaseolus mungo, Raphanus sativus and Vigna unguiculata (Ahmed et al., 1972). Leaf extract of Lantana is highly toxic to water hyacinth (Eichhornia crassipes). It suppressed the emergence of leaf buds and cause decay of its leaves and chlorophyll content by foliar spraying. Leaf extracts of L. camara exhibit a phytotoxic potential against other plants, especially against the germination of spores of the liverwort Asterella angusta (Kothari \& Chaudhary, 2001). Leaf extract of Lantana in high concentration inhibits the growth of Parthenium hysterophorus in flowering stage (Mishra, 2014). Sahid and Sugau (1993) studied the allelopathic potential of Lantana on germination and growth of five crops (Chinese cabbage, spinach, rapeseed, cucumber and chili) in laboratory, greenhouse, and field conditions, and found that emergence and dry weight of bioassay species were affected when Lantana debris was present on the soil surface or incorporated into the soil. Germination of Chinese cabbage, chili, and rapeseed decreased progressively when exposed to increasing concentrations of aqueous Lantana extract. The allelopathic effects of dried Lantana shoot residues on growth (shoot and root length and dry weight) over a 30-day period of wheat, corn, soybean, Virginia pepper weed and velvet leaf showed that corn was the most sensitive and wheat was least affected by Lantana residues (Mersie \& Singh, 1987).

Lantana roots possess more inhibitory quality than shoots (Achhireddy \& Singh, 1984). In soil amended with $1 \%(w / w)$ Lantana roots into $50 \%$ seedling of milkweed vine (Morrenia odorata Lindl.) died within 15 days after germination, higher seedling mortality was observed in higher concentrations of roots in soil. Lantana roots incorporated into the soil produced foliar symptoms such as wilting and desiccation, whereas Lantana shoots incorporated into the soil produced yellowing of the foliage of milkweed vine. Lantana residue showed more strong allelopathic effect after decomposition for 4 weeks prior to the planting of milkweed vine seeds. Root leachate of L. camara has potential to control soil borne root infecting fungi (Shaukat \& Siddiqui, 2002). They found suppression effect of $44 \%$ and $51 \%$, respectively against Fusarium solani and Rhizoctonia solani over control in soil amended with full strength root leachate on mung bean (Vigna radiata).

\section{Impact on Cattle}

The leaves of Lantana are toxic to most animals. Lantana has been major contributors to poisoning of cattle, buffalo, sheep and goats. The plant is not relished by cattle but is reported to be browsed when pasturage is scarce. Cattle fed leaves (12-16 oz.) develop symptoms of severe jaundice, exfoliation of skin near muzzle, profuse salivation, severe dermatitis and appear dull (CSIR, 1962). The leaves and seeds of this species supposedly contain "Triterpenoids" which cause poisoning and photosensitivity. L.camara contains pentacyclic triterpenoids that cause hepatotoxicity and photosensitivity when ingested by grazing animals such as sheep, goats, bovines and horses. Palatability of Lantana leaves as fodder is least because of presence of toxic material lantadenes in its leaves, which is not 
reduced even after several weeks of anaerobic microbial reaction under silage making (Sastry \& Mahadevan, 1963; Sharma, 1988; Sharma et al., 1980). In tropical countries, the ripe blue/black berries of Lantana are eaten, but ingestion of the green berry leads to human fatalities (Ross, 1999; Morton, 1994).

\section{Positive Impacts of Lantana}

\section{Herbal Medicine}

Presence of toxic compounds in certain Lantana spp. makes it an important species to study its phytochemistry. First systematic study on the chemical constituents of $L$. camara was undertaken in 1943 by P. G. J. Louw when he reported the isolation of its main active principle Lantanin with molecular formula $\mathrm{C}_{32} \mathrm{H}_{44} \mathrm{O}_{5}$, which was renamed as Lantadene $\mathrm{A}$ by himself in 1948 when Lantadene $\mathrm{B}$, with molecular formula $\mathrm{C}_{33} \mathrm{H}_{48} \mathrm{O}_{5}$ was isolated from all parts of Lantana shrub (Louw, 1948). Lantadenes, is believed to be responsible for almost all the biological activities of Lantana (Barre et al., 1997) such as antipyretic, antimicrobial, antimutagenic, antimicrobial, fungicidal, insecticidal, nematicidal, and other biological activities. Secondary metabolites of Lantana such as alkaloids, terpenoids, phenolics, iridoid glycosides, furanonaphthoquinones, flavonoids, phenyl ethanoid glycosides and miscellaneous compounds could be held partially responsible for some of these biological activities (Barre et al., 1997). The early work on Lantana spp. was concerned with studies on the essential oils; the maximum yield obtained by hydro distillation from the leaves reached $0.2 \%$ and, from the flowers, up to 0.6\% (Ahmed et al., 1972, Gildermeister \& Hoffmann, 1961). The chemical composition of essential oils obtained from Lantana depends on season, geographical location, and developmental stage of the plant (Randrianalijaona et al., 2005). Lantana has $31 \%$ hot water soluble fiber, $26 \%$ cellulose, $21 \%$ hemi-cellulose and $16.2 \%$ lignin of dry weight. Throughout the world studies on antibacterial properties of $L$. camara has been carried out extensively (Singh et al., 1990; Siddiqui et al., 1995; Deena \& Thoppil, 2000; Mello et al., 2005; Verma \& Verma, 2006). It is used as a sudorific, intestinal antiseptic, diaphoretic, and in treatment of tetanus and rheumatism and malaria in Indian medicine (Ojha \& Dayal, 1992). Extracts from the leaves exhibit antimicrobial, fungicidal, insecticidal and nematicidal activity (Begum et al., 2000; Day et al., 2003; Girish, 2017). It is useful for fistulae, pustule and tumours. A decoction of the plant is given in tetanus, rheumatism, malaria and atoxy of abdominal viscera (CSIR, 1962). Pounded leaves are applied to cuts, ulcers and swellings. A decoction of leaves and fruits is used as a lotion for wounds. An infusion of leaves is taken internally for bilious fever and catarrhal affections, externally it is used in the form of lotion or fomentation against eczema eruptions and rheumatism. An infusion of flowers is given as pectoral for children (CSIR, 1962; Singh et al., 1984). Stems are used as tooth brush and leaves for polishing wood.

\section{Industrial Uses of Lantana}

Originally introduced to most countries as a garden ornamental, in some countries it was planted as hedge to contain or keep out livestock (Bradely, 1988; Ghisalberti, 2000). While this plant has often described as 'weed', research community is exploring various 
uses of the plant, particularly potential of chemical constituents, such as Lantana oil (Sharma \& Sharma, 1989; da Silva et al., 1999). Plants in the Western Himalayan foothill zone of India yield $200 \mathrm{mg}$ of essential oil (market price US\$ 91/kg) from hydrodistillation of 5 quintal of Lantana biomass. In addition to perfume ingredient, essential oil from the leaves possess adultticidial activity against the different mosquito species. Thus this species can be utilized for oil-based insecticides as supplementary to synthetic insecticides (Dua et al., 2010; Kumar \& Maneemegalai, 2008). The leaves yield (0.2\%) yellow and greenish yellow oil with a pleasant and lasting odour reminiscent of sage (Salvia officinalis Linn.) on steam distillation. On standing, the oil becomes viscid and insoluble in alcohol. The leaf oil is used in the treatment of itches of skin and also useful as an antiseptic for wounds. The bark of the stem and roots contain a quinine-like alkaloid, lantanine, with strong antipyretic and antispasmodic properties. Acid extracts of the shoots show antibacterial activity against Escherichia coli. Acetated buffer extracts are active against Micrococcus pyogenes var. aureus. Lantana flowers yield $0.07 \%$ of a volatile oil similar to that of leaf oil. The flower contains anthocyanin, a yellow flavone, a pink pigment and carotene. The seed contain oil (9\%) with fatty acids components like linolenic, linoleic, oleic, stearic and palmitic. High content of cholesterol in leaves are also reported (Goyal \& Kamal, 1984).

Roots of Lantana are rich source of oleanolic acid which shows anti-inflammatory, hepatoprotective, anti-tumour, anti-oxidant, and anti-hyperlipidemic activity (Sharma \& Sharma, 1989). Uses of Lantana extract as herbal medicine are known in the folk medicine (Sastri, 1962; Kirtikar \& Basu, 2000; Ghisalberti, 2000) for the treatment of chicken pox, measles, asthma, skin itches, antiseptic for wounds, and externally in leprosy. Extract from this plant exhibit promising cytotoxicity against A375 cells (malignant skin melanoma) and Jurkat leukemia cell line (Ghosh et al., 2010; Badakhshan et al., 2009). Thus this plant is a prospective candidate for designing novel therapeutic agent and identification to find new anti-cancer agents. In an experiment with rodents (Mastomys coucha) the crude extract from stem of Lantana by oral route shows antifilarial efficacy (Mishra et al., 2007) by killing $40 \%$ of adult Brugia malayi parasites and sterilizing three fourth of the female worms. Antimicrobial efficacy of the plant (flavonoids, crude alkaloids, leaf extract, and essential oil) has been well documented against various microorganisms (Ventataswamy et al., 2010; Kurade et al., 2010; Sharma \& Kumar, 2009). Extracts of L. camara may be used for protection of members of brassicaceae family (e.g., mustard) against the aphid Lipaphis erysimi (Srivastava \& Guleria, 2003). The acetone extract of leaf has a great value to control the harmful aquatic snails (Lymnaea acuminata), and other molluscan pests as shown by the molluscicidal potential (Chauhan \& Singh, 2010) against freshwater snail (an intermediate host of liver fluke in cattle and livestock). Extract of leaves (5\% chloroform) was found significantly effective against termite worker (Verma \& Verma, 2006). The use of extract from plant has also been suggested as potential biocide against water hyacinth (Saxena, 2000) and nematodes (Begum et al., 2000).

Lantana biomass could be utilized as fertilizer, energy, fuel wood, pulp, paper fiber and developing roofing material (NAS, 1981). It could be a good raw material for paper and pulp industry. The stalks have been tried as raw materials for paper pulp and contain furfuroids $(21.6 \%)$, lignin $(14.0 \%)$, cellulose $(30.6 \%)$ and ash $(3.50 \%)$. Digestion with lime and kollerganging yield $63.7 \%$ of pulp suitable for wrapping paper and straw board. Pulp suitable for writing and printing paper is obtained by sulphate process 
(Anonymous, 1970-1988). Pretreatment of Lantana wood further improves the uses (i) to produce pulp suitable for writing and printing (Gujral \& Vasudevan, 1983), and (ii) low cost feedstock for bioethanol production (Pasha et al., 2007; Khud et al., 2010). Lantana biomass is used directly for various purposes and most important is as supplementary fuelwood for cooking and heating by people. Lantana wood has $18.53 \mathrm{MJ}$ energy kg-1, it yields 1181 biogas $1000 \mathrm{~kg}^{-1}$ and 561 methane $1000 \mathrm{~kg}^{-1}$ dried biomass. In a few Himalayan mountain villages it accounts for about $20 \%$ of the total firewood consumption (Negi \& Bhatt, 1993; Sharma \& Singh, 1994). This plant has also been used as sole substrate for oyster mushroom cultivation, however bioconversion was found lower than the wheat straw (Vats et al., 1994).

Growth potential of Lantana can be utilized for harvesting the solar energy utilization of biomass for various productive uses. This strategy could be useful in control of Lantana weed and simultaneously better utilization of alien species. It regenerates very fast even after lopping and attains high biomass yields (Joshi, 2002). Among other uses, making furniture from Lantana is a direct utilization of biomass from the wild. Lantana stems though are thin the wood is very tough and durable and thus useful for various handicrafts such as wickerwork. The Soliga of Karnataka is now-a-days utilizing Lantana in their wickercraft as bamboo resources are scarce and costly and the bamboo forests have been invaded by Lantana. By selectively harvesting Lantana for their craft, they are again able to make a living, as well as assisting the recovery of the native ecosystem and reducing the risk of wildfires (http://www.atree.org/lcc products). Similarly, tribal communities around Mudumalai Tiger Reserve in India are making such furniture which resembles cane furniture in design and performance but cost almost half. Another initiative under the name WELFARE (Women Empowerment through Lantana Furniture and Artifacts and Restoration of Environment) in the fringe of Corbett National Park, India has been launched to explore business opportunity of Lantana weed through training to make furniture from this termite resistant weed. Lantana sticks are extensively used for making baskets for packing and transport of vegetables to distant markets in some parts of Himalayan mountains. Leafy twigs of Lantana are kept in the bottom of grain containers to avoid termites, mice and other insects. In the areas of dominant presence over the landscape it provides shelter and vital winter food for many birds. Many birds utilize Lantana thickets when their natural habitat is unavailable. Lantana is also a major source of nectar for many butterflies and moths. In view of its multiple uses and invasive nature it has been suggested that use of L. camara need to be promoted in herbal ethno-medicine, biofuels and handicrafts (Chaterjee, 2015).

\section{Mulching for Soil Fertility}

In spite of the invasive and allelopathic effects, L. camara provides a good covering to the ground with fine leaf mulch (Munir, 1996) that improves the fertility of rocky, grave, or hard laterite soils, and serves to retain humus in deforested areas and checks soil erosion (https://en.wikipedia.org/wiki/Lantana_camara). Leaves are rich in nitrogen $(0.94 \%)$ and poor in lignin and decompose fast; thus leaves are good source of nutrients and can be utilized for biomass production in barren and infertile soils. The leaves and the twigs are occasionally used as green manure in forest areas and for paddy crops in Mysore; they can also be composted along with other materials. Analysis of 
green materials revealed $N=0.88 \% ; P=0.15 \% ; \mathrm{K}=0.90 \%$; and $\mathrm{Ca}=0.61 \%$. Lantana ash (ash content $=10.29 \%$ ) is rich in soluble potassium salts and useful for manuring coconut trees (Munir, 1996). It is also rich in manganese (0.3-0.4\%), potassium (1.1-1.8 $\%$ ) and phosphorus (1.6-2.2\%). The ash (10.9\% of plant wt.) is rich in soluble potassium salts (Vasudevan \& Jain, 1991) and enriches the soil (CSIR, 1962).

In the Western Himalayan mountains in India several workers have found Lantana (leaf) mulch improving soil fertility and moisture retention (Acharya \& Bhagat, 1984; Sharma \& Acharya, 2000), enhance root growth, nutrient uptake and grain yield of maize and wheat (Acharya \& Sharma, 1994). Sharma and Parmar (1998) found that mulching with Pine and Lantana increased the phosphorus-use efficiency and yield of wheat. Lantana mulching has been found to improve soil hydraulic properties to the benefit of the wheat crop in a rice-wheat cropping sequence (Sharma \& Verma, 2000; Bhushan \& Sharma, 2005). In an experiment (Kumar et al., 2009) found that Lantana leaves could be suitably mixed with forest tree leaves for hastening decomposition and nutrient release, soil moisture conservation, soil fertility maintenance and increase in yield of wheat and rice in rainfed crop fields. Negi \& Kandpal (2003) found that Lantana mulch improves soil fertility owing to fast decomposition (Lantana leaves take 323 days for complete decomposition) and nutrient release. Sharma and Acharya (2000) in wheat (Triticum aestivum L.)- maize (Zea mays L.) crop rotation in rainfed areas of north-west India using fresh Lantana biomass as mulch found most effective in conserving rainwater (range $=7.1-22.2 \mathrm{~mm}$ across different soil depths, tillage treatments and date of sowing) that ultimately increased the yield of wheat and maize. They found that after four cropping cycles, organic carbon content in $0-15 \mathrm{~cm}$ soil layer of mulched plots was significantly higher (11.3-12.3 $\mathrm{g} \mathrm{C} \mathrm{kg}^{-1}$ ) than control (conventional practice) plots $\left(9.0 \mathrm{~g} \mathrm{C} \mathrm{kg}^{-1}\right)$. In north-east India, cultivation of tuber crops and vegetables on hill slopes involve putting of dried vegetation mainly Khasi pine (Pinus kesiya) along with weeds like Imperata cylindrica and L. camara to control soil erosion and conserve soil moisture (Mishra \& Saha, 2007).

\section{Other Uses of Lantana}

Some other positive aspects of Lantana include: (i) It accumulates mercury from the soil and transport it into the shoot, and after reduction releases the mercury vapour into the atmosphere (Vasudevan \& Jain, 1991). Thus Lantana can be used in managing biochemistry of mercury both at reservoirs and in the transfer of the element between soil and atmosphere, (ii) Leaves of L. camara may act as biomonitoring tool for air quality by detecting suspended dust particles in air (Rai \& Singh, 2015). This plant is recently used in advanced techniques such as phytoremediation of particulate pollution, phytoextraction of heavy metals (Kumar et al. 2016) such as lead (Saini et al. 2017), (iii) Larvicidal activity of $L$. camara leaf extract reported against three mosquito species has a potential to be used as biopesticide, Hemalatha et al, 2015 (iv) Lantana leaves have been tried as a substitute for tea. Fermented leaves possess a mild odour which is not unpleasant, and yield an inferior beverage. The leaves contain a powerful oxidase. They also contain catalase, amylase, invertase, lipase, tannase and glucosidase. Appreciable amounts of tannins and sugar, and a resin occur in leaves. A crystalline glucoside (probably $\mathrm{C}_{27} \mathrm{H}_{42} \mathrm{O}_{4}$ ) has been separated from the resin by ether extraction (https:/en. wikipedia.org/wiki/Lantana_camara), (v) Lantana is useful as honey plants, and 
Spanish Flag (L. camara), L. lilacina and L. trifolia are sometimes planted for this purpose, or in butterfly gardening. Butterflies which are attracted to Lantana flowers are most notably Papilioninae (swallowtail and bird wing butterflies). Hesperiidae (skippers) and certain brush-footed butterflies, as well as some Pieridae and Lycaenidae, also like to visit the flowers, and (vi) The fruit is a delicacy for many birds like the Yellow-fronted White-eye of Vanuatu, the Superb Fairy-wren in Australia, or the Mauritius Bulbul, which help in the dissemination of seeds.

\section{Eradication and Management of Lantana}

Various methods such as mechanical, cultural, chemical and biological, have been tried to control the Lantana proliferation. Early records of Lantana control underscore the importance of completely uprooting Lantana after cutting and burning aboveground biomass to prevent it recolonising from the rootstock (Tireman, 1916; Pereira, 1919). Babu et al. (2009) and Love et al. (2009) devised a method for eradicating Lantana using knowledge about its ecology, and, subsequently, weed-free landscapes were restored to productive grasslands. Control measure by mechanical means include stumping of plants in February or March up to a height of $1 \mathrm{ft}$. above the ground and burning the cuttings; the stumps left behind are pulled out in the rainy season when the ground is soft. Frequent uprooting of regrowth, which appear after the first cutting; for 2-4 years is essential to keep the pest under control. Another method is to cut the branches and heap the debris around the roots to prevent regeneration of new shoots. The debris is then burnt, followed by digging up of the root system and burning (Babu et al., 2009). Among the removal techniques such as cutting, burning and uprooting the former two were found more effective but recovery of native vegetation across these three techniques was found almost similar (Sundaram et al. 2018). Also, uprooting followed by weeding after rainy season was found crucial to long-term Lantana eradication success (Prasad et al. 2018).

Control of Lantana by the use of chemicals has given useful results. Experiments conducted to control L. camara in Shiwalik hills of Punjab through chemical treatment (Glyphostate $1.0 \%$ spray at stump level) and by planting four fast-growing species viz. Dendrocalamus strictus, Leucaena leucocephala, Albizia procera and Melia azedarach with Lantana showed that plantations of the fast growing species hinder the growth of L. camara, and help increase the biomass of palatable species within a short period 23 years (Luna et al., 2009). Another methods tried consists of cutting the plants close to the ground and painting cut ends with sodium arsenate. The treatment is effective but it is not recommended as it involves the hazards of poisoning livestock which may stray into the treated area. In recent years various herbicides have been applied and successful control has been achieved. Painting of cut ends with 2,4-D solution (10\%) gives effective control. Trials carried out in India at the Agricultural Research Station, Ambalavayal and the Fruit Research Station, Kallar (Madras) have shown that shrubs cut to a height of $60 \mathrm{~cm}$ from the ground and sprayed with 2,4,5-T (20 lb) in a spray volume of 150 gal./acre, using Teepol as wetting agent, withered in 15 days. Spraying trials at the Forest Research Institute, Dehra Dun showed that Y.F. 2717-2, 4, 5-T, nbutyl ester is effective even when the plants are not cut back. Formulations containing 2, 4, 5-T alone or in combination with 2, 4-D are more effective than 2, 4-D alone, 
especially in large bushes. Regrowth after cutting back, can be completely controlled by spraying with Dicotox, Esteron 44 (active principle, 2,4-D ester), MCPA and Fernoxone (https://en.wikipedia.org/wiki/Lantana_camara).

Biological control of Lantana has been attempted with limited success. In Australia, about 30 insects have been introduced to control the spread of Lantana, and this has caused problems of its own. For example, The Lantana Bug Aconophora compressa) is a polyphagous species introduced in 1995 that feeds on dozens of plants, and not only has it failed to have a noticeable impact on the Lantana population, it has even become a pest in horticulture, parasitizing the related fiddlewoods (Citharexylum spp.). The small Lantanafeeding moths, Epinotia lanata and Lantanophaga pusillidactyla, while not becoming pests, have nonetheless failed to stem the spread of the invasive weed, as has the Lantana Scrub-hairstreak butterfly (Strymon bazochii) which was introduced to control Lantana on the Hawaiian Islands. Biological control of Lantana by insects is reported to have met with some success in Hawaii and Fiji island; Lantana bug (Orthezia insignis Dougl.), Lantana seed fly [Ophiomyia (Agromyza) lantanae Frog] and Lantana lace bug (Teleonemia scrupulosa Stal) feed on stem, leaves flowers and seeds and prevent the spread of the plant. The introduction of the foreign insects into India for Lantana control has been attempted, but it has not been pursued pending further knowledge on the effect of introduction on other plants. Complete eradication of Lantana over large areas is difficult and costly (CSIR, 1962). Cultural control has been attempted by planting Ricinus communis Linn. or Leucaena glauca Benth., while in Srilanka, Tithonia diversifolia A. Gray is reported to have given good results (CSIR, 1962).

Besides mechanical and chemical control methods, burning is used as a method to control L. camara. This practice needs to be discouraged because it could promote rather than check - the spread of $L$. camara in burnt areas. In this way a positive feedback between invasive species and fire occurs, which can result in major community- and ecosystem-level effects, changing local community dynamics, altering biodiversity, and generating long-lasting consequences on biogeochemical cycles (Hiremath \& Sundaram, 2005).

\section{Ecological Success of Lantana}

It is difficult to attribute the success of Lantana to any one factor alone. The ability of invasive species to preemptively take advantage of resources (light, soil nutrients, space) following a disturbance, species poor ecosystem, lack of natural enemies to keep it in check, freedom from enemies, and antimicrobial or allelopathic chemicals they exude from roots, which may inhibit germination and establishment of other species in their new environments are several factors which could be responsible for aggressive invasion of Lantana in India (Sharma \& Raghubanshi; http://www. currentconservation.org). There are some chemicals, such as Lantadene A (the active principle of L. camara) and Lantadene B (Louw, 1948), when released in surroundings these chemicals interfere and inhibits germination and growth of many species (Ambika et al., 2003; Bais et al., 2006). Equipped with these features, L. camara has potential to prevent natural regeneration of some tree species, block natural succession and replace native species (Morton, 1994; Ambika et al., 2003). Thus ultimately it threatens biodiversity of naturalized areas (Kohli et al., 2004). Niphadkar et al. (2016) 
have reported that moist deciduous forests facilitate the growth and spread of $L$. camara in tropical hotspot regions of India.

Lantana possesses unique traits to withstand environmental stress in new environment such as fast spreading ability though vegetative and reproductive growth, wide adaptability and ecological adaptations. It propagates readily from stumps and cuttings and from seed, which are disseminated by birds through droppings. It regenerates quickly after cutting, trampling or burning and forms a dense impenetrable thicket and it becomes nearly impossible to eradicate this weed. For wide adaptation in the new environment it could undergo to genetic changes due to selection pressure and respond quickly to anthropogenic disturbances like other invasive plants (Sakai et al., 2001). Its proliferation and spread are attributed to a number of factors including natural propagation, high tolerance to herbicides and decreased competition from other weeds (Phillips \& Tucker, 1976), and non-palatability and toxic to cattle.

What are the ecological mechanisms underlying the success and persistence of Lantana? One potential mechanism relates to its tolerance to being burnt. Hiremath and Sundaram (2005) has hypothesised that there may be a positive feedback between present-day fires and invasion by Lantana, leading to a fire-Lantana cycle that can have deleterious compositional and functional consequences for forest ecosystems. Recent findings from other parts of the tropics confirm that Lantana may be favoured by disturbances such as fire and grazing (Duggin \& Gentle, 1998). In fact, recent evidence suggests that Lantana actually regrows more densely in response to being burnt (Gentle \& Duggin, 1997). The high productivity of Lantana rapidly yields large quantities of biomass, which can fuel further fires (Bingelli et al., 1998). Thus, forests once colonized by Lantana can well fall victim to a fire-Lantana cycle, perpetuating Lantana to the detriment of other vegetation. A second potential mechanism underlying the success of Lantana is its ability to compete for scarce nutrients. Lantana is exceedingly efficient at nutrient uptake and use, enabling it to grow on highly impoverished soils (Bhatt et al., 1994; Rawat et al., 1994, Sharma \& Raghubanshi, 2009). Such an ability to extract and use nutrients efficiently would give it a competitive advantage over other species in low-fertility environments (Tilman et al., 1997), for example, in forests already degraded by frequent burning. Finally, a third potential mechanism underlying the success of Lantana is its colonizing ability. Lantana's abundant perennially available flowers and fruits make it a good host for pollinators and frugivores, respectively, and ensure a year-round supply of well-dispersed propagules. Even in places where Lantana is completely uprooted, it regenerates profusely from seeds in the soil seed bank and root suckers for several years following its removal. Thus, a complete eradication of Lantana requires repeated uprooting of successive crops for several consecutive years (Tireman, 1916). Thus, Key biological attributes of Lantana that make this species among the world's 100 worst invasive weeds include fitness homeostasis, phenotypic plasticity, widespread dispersal by birds that feed on its fruit, a broad geographic range, vegetative reproduction, fire tolerance, ability to compete effectively with the native flora, and allelopathy (Munir, 1996).

\section{Conclusion}

This review on ecology and use of Lantana camara highlights its biomass productivity, reproductive biology, invasiveness, allelopathy, eradication measures and economic 
uses reported from India. Among its negative aspects, invasion into agricultural landscapes, forests and wastelands are the most important that cause deteriorates biodiversity, and harms commercial interests of farmers and foresters. Its allelopathic impacts are also notable on certain food crops, and its toxic effect on cattle is also an issue. Thickets of Lantana also provide shelter to wild animals and promote manwildlife conflicts. Lantana acting as a vehicle of forest fire is the most serious issue that demands further research. In large tracts of our country it has emerged as the most obnoxious weed that demands heavy efforts for its eradication.

Among the positive aspects its industrial use in medicine, cosmetics and insect repellents alone has a vast potential. Another major area of its use has been found in raising soil fertility and soil and water conservation thus beneficial for agriculture. Among other uses, its huge biomass production potential for bio-energy, substrate for growing mushroom, tensile sticks for furniture, basket making and insect repellent in traditional granaries hold good opportunities for utilization of this weed for cottage industry. Good butterfly diversity can be found around Lantana flowers as this species is mostly pollinated by butterflies. Fruits are delicacy for many birds. It is thus useful as a honey plant and used for butterfly gardening. It can be pointed out that the positive impacts and economic uses may outweigh the negative impacts and require further studies on cost-benefit considerations for its management.

Acknowledgements Authors wish to thank Dr. R.S. Rawal, Director, G.B. Pant National Institute of Himalayan Environment \& Sustainable Development, Kosi-Katarmal, Almora, India for providing necessary facilities to write this manuscript.

Open Access This article is distributed under the terms of the Creative Commons Attribution 4.0 International License (http://creativecommons.org/licenses/by/4.0/), which permits unrestricted use, distribution, and reproduction in any medium, provided you give appropriate credit to the original author(s) and the source, provide a link to the Creative Commons license, and indicate if changes were made.

\section{References}

Acharya, C.L. \& P.D. Sharma.1994. Tillage and mulch effects on soil physical environment, root growth, nutrient uptake and yield of maize and wheat on an Alfisol in north-west India. Soil and Tillage Research 32: 291-302.

Acharya, C.L. \& R.M. Bhagat. 1984. Infiltration behaviour, root development and yield of rain fed maize (Zea mays L.) under different soil management practices. Proceedings of the Indian National Science Academy (Part B) 50: 441-448.

Achhireddy, N.R. \& Megha Singh. 1984. Allelopathic effect of Lantana (Lantana camara) on Milkweed vine (Morrenia odorata). Weed Science 323: 757-761.

Adhikari, B.S., S.K. Uniyal \& G.S. Rawat. 2009. Vegetation structure and community patterns of Tehri Dam submergence zone, Uttarakhand, India. EurAsian Journal of BioSciences 3: 40-49.

Ahmed Z.F., A.M. El-Moghazi Shoaib, G.M. Wassel \& S.M. El-Sayyad. 1972. Phytochemical study of Lantana camara- D Part 1. Planta Medica 21: 282-288.

Ambika, S.R., S. Poornima, R. Palaniraj, S.C. Sati \& S.S. Narwal. 2003. Allelopathic plants. 10. Lantana camara L. Allelopathy Journal 12: 147-162.

Babu, S., A. Love \& C.R. Babu. 2009. Ecological restoration of Lantana-invaded landscapes in Corbett Tiger Reserve, India. Ecological Restoration 27: 467-477.

Badakhshan, M.P., S. Sreenivasan, R. N. Jegathambigai \& S. Ramanathan. 2009. Anti-leukemia activity of methanolic extracts of Lantana camara. Pharmacognosy Research 1: 274-279. 
Bais, H.P., T.L. Weir, L.G. Perry, S. Gilroy \& J.M. Vivanco. 2006. The role of root exudates in rhizosphere interactions with plants and other organisms. Annual Review of Plant Biology 57: 233-266.

Barre, J.T., B.F. Bowden, J.C. Koll, J. De Jesus, V. De La Fuente, G.C. Janairo \& C.Y. Ragasa. 1997. A bioactive triterpenoid from Lantana camara. Phytochemistry 4: 321-324.

Begum, S., A. Wahab, B.S. Siddiqui \& F. Qamar. 2000. Nematicidal constituents of the aerial parts of Lantana camara. Journal of Natural Products 63: 765-767.

Bhatt, Y.D. 1990. Structure and function of Lantana camara shrubland in the Central Himalaya. Ph.D. Thesis, Kumaun University, Nainital.

Bhatt, Y.D., Y. S. Rawat \& S. P. Singh. 1994. Changes in ecosystem functioning after replacement of forest by Lantana shrubland in Kumaun Himalaya. Journal of Vegetation Science 5: 67-70.

Bhusan, L. \& P.K. Sharma. 2005. Long-term effects of Lantana residue additions on water retention and transmission properties of a medium-textured soil under rice-wheat cropping in northwest India. Soil Use and Management 21: 32-37.

Binggeli, P. 1999. Data sheet: Lantana camara. In Crop Protection Compendium. CAB International, Wallingford.

Binggeli, P., J.B. Hall \& J.R. Healey. 1998. An Overview of Invasive Woody Plants in the Tropics. School of Agriculture and Forest Sciences Publication Number 13. University of Wales, Bangor, UK.

Bisht, M.S. \& A.K. Dobriyal. 2002. Distribution and habitat preferences of the pheasants in the Garhwal Himalaya. Journal of Hill Research 15(1): 12-15.

Bisht, M.S., S. Bhandari \& A.K. Dobriyal. 2012. Invasive vegetation in the forests of Garhwal Himalaya: Distribution and effect on bird diversity. In: G.C.S. Negi \& P.P. Dhyani (Eds.), Glimpses of Forestry Research in the Indian Himalayan Region. G.B. Pant Institute of Himalayan Environment and Development, Almora \& M/s Bishen Singh Mahendra Pal Singh, Dehradun, India. pp. 159-166.

Bradely, P.N. 1988. Survey of woody biomass on farms in Western Kenya. Ambio 17: 40-48.

Chandrasekaran, S. \& P. S. Swamy. 2002. Biomass, litterfall and aboveground net primary productivity of herbaceous communities in varied ecosystems at Kodayar in the western ghats of Tamil Nadu. Agriculture, Ecosystems and Environment 88: 61-71.

Chaterjee, R. 2015. Impact of Lantana camara on the Indian society. International Journal of Environment 4(2): 348-354.

Chaturvedi, O.P. 1983. Biomass structure, productivity and nutrient cycling in Pinus roxburghii forest. Ph.D. Thesis, Kumaun University, Nainital.

Chauhan, S. \& A. Singh. 2010. Molluscicidal potential of Lantana indica and Alstnia scholaris plants against freshwater snail Lymnaea acuminata. Internet Journal of Toxicology 7(2).

CSIR. 1962. The Wealth of India (Raw Material) Vol. 6. pp. 31-35. Council of Scientific and Industrial Research, New Delhi.

da Silva, M.H.L., E.H.A. Andrade, M.D.B. Zoghbi, A.I.R. Luz, J.D. da Silva \& J.G.S. Maia. 1999. The essential oils of Lantana camara L. occurring in north Brazil. Flavour and Fragrance Journal 14: 208-210.

Day, M., C.J. Wiley, J. Playford \& M.P. Zalucki. 2003. Lantana: current management status and future prospects. ACIAR Monograph 102: 28.

Deena M.J. \& J.E. Thoppil. 2000. Antimicrobial activity of the essential oil of Lantana camara. Fitoterapia 71: 453-455.

Dobhal, P.K., R.K. Kohli \& D. R. Batish. 2010. Evaluation of the impact of Lantana camara L. invasion, on four major woody shrubs, along Nayar river of Pauri Garhwal in Uttarakhand Himalaya. International Journal of Biodiversity and Conservation 2: 155-161.

Dua, V.K., A.C. Pandey, \& A.P. Dash. 2010. Adulticidal activity of essential oil of Lantana camara leaves against mosquitoes. Indian Journal of Medical Research 131: 434-439.

Duggin, J.A. \& C.B. Gentle. 1998. Experimental evidence on the importance of disturbance intensity for invasion of Lantana camara L. in dry rainforest open forest ecotones in north-eastern NSW, Australia. Forest Ecology and Management 109: 279-292.

Gentle, C.B. \& J.A. Duggin. 1997. Lantana camara L. invasions in dry rainforest-open forest ecotones: the role of disturbances associated with fire and cattle grazing. Australian Journal of Ecology 22: 298-306.

Ghisalberti, E.L. 2000. Lantana camara L. (Verbenaceae). Fitoterapia 71: 467-486.

Ghosh S., M. Das Sarma, A. Patra \& B. Hazra. 2010. Anti-inflammatory and anticancer compounds isolated from Ventilago madraspatana Gaertn., Rubia cordifolia Linn., and Lantana camara Linn. Journal of Pharmacy and Pharmacology 629: 1158-1166.

Gildermeister, E. \& F.R. Hoffmann. 1961. A“etherischen O”le, Vol. VI., Berlin, Akademie-Verlag.

Girish, K. 2017. Anti- microbial activities of Lantana camara Linn. Asian Journal of Pharmaceuticals and Clinical Research 10(3): 57-67. 
Goyal, M.M. \& K. Kamal. 1984. High content of cholesterol in the leaves of Lantana indica Roxb. Indian Drugs 22: 41.

Gujral, G.S. \& P. Vasudevan. 1983. Lantana camara L., a problem weed. Journal of Scientific and Industrial Research 42: 281-286.

Hakimuddin, M. 1929. Lantana in Northern India as a pest and its probable utility in solving the cowdung problem. Indian Forester 56: 405-410.

Heirro J.L. \& R.M. Callaway. 2003. Allelopathy and exotic plant invasion. Plant and Soil 256: 29-39.

Hemalatha, P., D. Elumalai, A. Janaki, M. Babu, K. Velu, K. Velayutham \& P.K. Kaleena. 2015. Larvicidal activity of Lantana camara aculeata against three important mosquito species. Journal of Entomology and Zoology Studies 3(1): 174-181.

Heywood, V. H. 1989. In: Biological Invasions: A Global Perspective. Drake, J. A. et al., editors. John Wiley and Sons, New York, 1989, pp. 31-60.

Hilje, L. 1985. Insectos visitadores y efficiencia reproductiva de Lantana camara L. (Verbenaceae). Brenesia 23: 293-300.

Hiremath A.J. \& B. Sundaram. 2005. The fire-Lantana cycle hypothesis in Indian forests. Conservation and Society 3: 26-42.

Holm, L., J.V. Pancho, J.P. Herberger \& D.L. Plucknett. 1979. A Geographical Atlas of World Weeds. Wiley, New York.

Jim Corbett 1944. Man Eaters of Kumaun. Oxford, India. 37 p.

Joshi, A.P. 2002. Lantana. Himalayan Environment Studies and Conservation Organization, Vigynanprasth, Dehradun.

Khud, R.C., R. Gupta, Y.P. Khasa, \& A. Singh. 2010. Bioethanol production from Lantana camara (red sage): Pretreatment, saccharification and fermentation. Bioresource Technology 101: 8348-8354.

Kimothi, M. M., D. Anitha, H.B. Vasistha, P. Soni \& S.K. Chandola. 2010. Remote sensing to map the invasive weed, Lantana camara in forests. Tropical Ecology 51: 67-74.

Kirtikar, K.R. \& B.D. Basu. 2000. Indian Medicinal Plants. Indological and Oriental Publishers, Vol. 8, 3rd edition, pp. 2634-2636, New Delhi.

Kohli, R.K., K.S. Dogra, D.R. Batish \& H.P. Singh. 2004. Impact of invasive plants on the structure and composition of natural vegetation of northwestern Indian Himalayas. Weed Technology 18: 1296-1300.

Kohli, R.K., D.R. Batish, H.P. Singh \& K.S. Dogra. 2006. Status, invasiveness and environmental threats of three tropical American invasive weeds (Parthenium hysterophorus L., Ageratum conyzoides L., Lantana camara L.) in India. Biological Invasion 8: 1501-1510.

Kothari M. \& B.L. Chaudhary. 2001. Allelopathic effects of L. camara on spore germination of Asterella angusta- a liverwort. Indian Journal of Experimental Biology 39: 1194-1198.

Kugler, H. 1980. The pollination of Lantana camara. Flora 169: 524-529.

Kumar, M.A. \& S. Maneemegalai. 2008. Evaluation of larvicidal effect of Lantana camara Linn. against mosquito species Aedes aegypti and Culex quinquefasciatus. Advances in Biological Research 2: 39-43.

Kumar, P., M. Pant \& G.C.S. Negi. 2009. Soil physico-chemical properties and crop yield improvement following Lantana mulching and reduced tillage in rainfed croplands in the Indian Himalayan mountains. Journal of Sustainable Agriculture 33: 636-657.

Kumar, R., R. Katiyar, S. Kumar, T. Kumar \& V. Singh. 2016. Lantana camara: An alien weed, its impact on animal health and strategies to control. Journal of Experimental Biology \& Agricultural Science 4(35): 321-337.

Kumar, V. \& B. Subramaniam. 1986. Chromosome Atlas of Flowering Plants, Dicotyledons. Botanical Survey of India, Kolkata, Vol. I.

Kurade, N.P., V. Jaitak, V.K. Kaul \& O.P. Sharma. 2010. Chemical composition and antibacterial activity of essential oils of Lantana camara, Ageratum houstonianum and Eupatorium adenophorum. Pharmaceutical Biology 48: 539-544.

Louw P.G.J. 1948. Lantadene A, the active principle of Lantana camara L. II. Isolation of Lantadene B and oxygen functions of lantadene A and lantadene B. Onderstepoort. Journal of Veterinary Science and Animal Industry 23: 233-238.

Love, A., D. Naik, S.K. Basak, S. Babu, N. Pathak \& C.R. Babu. 2009. Variability in foliar essential oils among different morphotypes of Lantana species complexes and its taxonomic and ecological significance. Chemistry and Biodiversity 6: 2263-2274.

Luna, R.K., R.K. Manhas, S. Banyal \& S.K. Kamboj. 2009. Effect of Lantana camara Linn. on biomass production and carrying capacity of forest areas of Shiwalik hills of Punjab. Indian Forester 135: 869-879.

Mack R., D. Simberloff, M. Lonsdale, H. Evans, M. Clout \& F. Bazzaz. 2000. Biotic invasions: cause, epidemiology, global consequences, control. Ecological Applications 10: 689-710. 
Maiti, P.P., R.K. Bhakat \& A. Bhattacharjee. 2008. Allelopathic effects of Lantana camara on physiobiochemical parameters of Mimosa pudica seeds. Allelopathy Journal 22(1): http://www.indianjournals. com/ijor.aspx? target=ijor:aj\&volume $=22 \&$ issue $=1 \&$ article $=006$.

Manda, G. \& S.P. Joshi. 2015. Eco- physiology and habitat invasibility of an invasive, tropical shurb (Lantana camara) in western Himalayan forest of India. Forest Science and Technology 11(4): 182-196.

Mello F.B., D. Jacobus, K. Carvalho \& J.R.B. Mello. 2005. Effects of Lantana camara (Verbenaceae) on general reproductive performance and teratology in rats. Toxicology 45: 459-466.

Mersie, W. \& Megha Singh. 1987. Allelopathic effect of Lantana on some agronomic crops and weeds. Plant and Soil 98: 25-30.

Mishra, A. 2014. Studies of allelopathic effect of Lantana camara in aqueous leaf extract on growth of Parthenium hysterophorus in flowering stage. Indian Journal of Applied Research 4(6): 33-35.

Mishra, N., M. Sharma, K. Raj, A. Dangi, S. Srivastava \& S. Misra-Bhattacharya. 2007. Chemical constituents and antifilarial activity of Lantana camara against human lumpatic filariid Brugia malayi and rodent filariid Acanthocheilonema viteae maintained in rodent hosts. Parasitology Research 100: 439-448.

Mishra, V.K. \& R. Saha. 2007. Characterization of soil health under different land use pattern in hilly ecosystem of Meghalaya. ENVIS Bulletin on Himalayan Ecology 15: 6-13.

Mooney, H. A. \& J.A. Drake. 1986. Biological Invasion of North America and Hawaii. Springer Verlag, New York, 1986.

Morton, J.F. 1994. Lantana, or red sage (Lantana camara L., Verbenaceae), notorious weed and popular garden flower, some cases of poisoning in Florida. Economic Botany 48: 259-270.

Munir, A. A. 1996. A taxonomic review of Lantana camara L. and L. montevidensis (Spreng.) Briq. (Verbenaceae) in Australia. Journal Adelaide Botanical Garden 17: 1-27.

NAS (National Academy of Sciences). 1981. Food from waste: pp. 142-157. In: Food, fuel and fertilizer from wastes. Report of the National Academy of Sciences, National Academy Press, Washington, D.C.

Nayar M.P. 1977. Changing patterns of the Indian flora. Bulletin Botanical Survey of India 19: 145-154.

Negi, G.C.S. 1989. Phenology and nutrient dynamics in tree leaves of Kumaun Himalayan forests. Ph.D. Thesis, Kumaun University, Nainital.

Negi, G.C.S. \& Y.D. Bhatt. 1993. Biomass utilization in a Central Himalayan village ecosystem. Pp. 133-146. In: Vir Singh, editor. Eco-Crisis in the Himalaya: Causes, Consequences and Ways Out. International Book Distributors, Dehra Dun.

Negi, G.C.S. \& K.D. Kandpal. 2003. Traditional methods of water management in the Central Himalayan agriculture. Indian Journal of Traditional Knowledge 2 (3): 256-264.

Niphadkar, M., G.F. Ficetola, A. Bonardi, H. Nagendra \& E. Padoa-schioppa. 2016. Effect of landscape context on the invasive species Lantana camara in Biligiri Rangaswamy Temple Tiger Reserve India. Tropical Ecology 57(1): 9-21.

Ojha, B.M. \& N. Dayal. 1992. Medicinal values and economic importance of an obnoxious weed Lantana. Journal of Economic and Taxonomic Botany 16: 595-598.

Parsons, W.T. 1992. In: Cuthbertson, E.G. (Ed.), Noxious Weeds of Australia. Melbourne: Inkata Press, 1992.

Pasha C., M. Nagavalli \& L.V. Rao. 2007. Lantana camara for fuel ethanol production using thermotolerant yeast. Letters in Applied Microbiology 44: 666-672.

Pereira, W.E. 1919. Lantana in the Math working circle in Savantavadi state forest. Indian Forester 46: 188193.

Phillips, R.L. \& P.H. Tucker. 1976. Evaluation of herbicides for Lantana control in citrus groves. Proceedings of Florida State Horticultural Society 89: 19-20.

Pimentel, D., S. McNair, J. Janecka, J. Wightman, C. Simmonds, C. O’Connell, E. Wong, L. Russel, J. Zern, T. Aquino \& T. Tsomondo. 2001. Economic and environmental threats of alien plant animal and microbe invasions. Agriculture, Ecosystems and Environment 84: 1-20.

Prasad, A., J. Ratnam \& M. Sankaran. 2018. Rainfall and removal method influence eradication success for Lantana camara. Biological invasion 10.100/10530-018-1785-1.

Raghubanshi, A.S. and A. Tripathi. 2009. Effect of disturbance, habitat fragmentation and alien invasive plants on floral diversity in dry tropical forests of Vindhyan highland: a review. Tropical Ecology 50(1): 57-69.

Rajwar, G.S. 2007. Invasive effects of Lantana camara in the forests of Southern Garhwal Himalaya. In: Yajun W, Shengcai L, Ping H, Yuzhong Y, Ying A, Xiuyun S. (Eds.) Progress in Environmental Science and Technology, Vol. I: Proceedings of the 2007.

Rai, P.K. \& M.M. Singh. 2015. Lantana camara invasion in urban forest of an Indo Burma hotspot region and its eco-sustainable management implication through bio-monitoring particulate matter. Journal of Asia Pacific Biodiversity 8 (4): 375-381.

Raizada, P. \& A.S. Raghubanshi. 2010. Seed germination behaviour of Lantana camara in response to smoke. Tropical Ecology 51(2S): 347-352. 
Rajendran, A. \& Daniel, P. 2002. The Indian Verbenaceae (A Taxonomic Revision), Bishen Singh Mahendra Pal Singh, Dehradun, 2002.

Ramakrishnan, P.S. 1991. Biological invasion in the tropics: an overview. In: P.S. Ramakrishnan (Ed.), Ecology of Biological Invasion in the Tropics. Published by National Institute of Ecology, International Scientific Publication, New Delhi. Pp. 1-19.

Rana, B.S., S.P. Singh \& R.P. Singh. 1989. Biomass and net primary productivity in Central Himalayan forests along an altitudinal gradient. Forest Ecology and Management 27: 199-218.

Randrianalijaona, J.A., P.A.R. Ramanoelina, J.R.E. Rasoarahona \& E.M. Gaydouet. 2005. Seasonal and chemotype influences on the chemical composition of Lantana camara L.: Essential oils from Madagascar. Analytica Chimica Acta 545: 46-52.

Rawat, Y.S. \& J.S. Singh . 1988. Structure and function of oak forests in Central Himalaya. I Dry matter dynamics. Annals of Botany 62:397-411.

Rawat, Y.S., Y.D. Bhatt, P. Pande \& S.P. Singh. 1994. Production and nutrient cycling in Arundinaria falcata and Lantana camara: The two converted ecosystems in Central Himalaya. Tropical Ecology 35: 53-67.

Ray, A. \& R. Ray. 2014. Rapid divergence of ecotypes of an invasive plant. AoB Plants 6: (doi: https://doi. org/10.1093/aobpla/plu052).

Ross, I.A. 1999. Medicinal plants of the world. Chemical constituents, traditional and modern medical uses. New Jersey, Humana Press.

Sahid, I.B. \& J.B. Sugau. 1993. Allelopathic effect of Lantana (Lantana camara) and Siam weed (Chromolaena odorata) on selected crop. Weed Science 41: 303-308.

Sahu, A.K. \& S. Panda. 1998. Population dynamics of a few dominant plant species around industrial complexes in West Bengal, India. Bombay National History Society Journal 95: 15-18.

Saini, V.K., S. Suthar, C. Karmveer \& K. Kumar. 2017. Valorization of toxic weed Lantana camara L. biomass for adsorptive removal of lead. Journal of Chemistry (Article ID 5612594, 12 pages).

Sakai, A.K., F.W. Allendorf, J.S. Holt, D.M. Lodge, J. Molofsky, S. Baughman, R.J. Cabin, J.E. Cohen, N.C. Allstrand, D.E. McCauley, I.M. O’Neil Parker, J.N. Thompson \& S.G. Waller. 2001. The population biology of invasive species. Annual Review of Ecology and Systematics 32: 305-332.

Sastri, B.N. (Ed.). 1962. Lantana Linn. (Verbenaceae). The Wealth of India: A Dictionary of Raw Materials and Industrial Products. Vol. VI, Council of Scientific and Industrial Research, New Delhi. P. 31-34.

Sastry, M.S. \& V. Mahadevan. 1963. Investigation of toxicity of Lantana camara Linn. Indian Veterinary Journal 7: 8-82.

Saxena, K.G. 1991. Biological invasions in the Indian subcontinent: review on invasion by plants. In: Ramakrishnan, P.S. (Ed.). Ecology of Biological Invasion in the Tropics, pp. 53-73. International Scientific Publishers, New Delhi, India.

Saxena, M.K. 2000. Aqueous leachate of Lantana camara kills water hyacinth. Journal of Chemical Ecology 26: $2435-2447$.

Schemske, D.W. 1976. Pollination specificity in Lantana camara and L. trifolia (Verbenaceae). Biotropica 8: 260-264.

Sharma, B. \& P. Kumar. 2009. Bioefficacy of Lantana camara L. against human pathogens. Indian Journal of Pharmaceutical Science 71: 589-593.

Sharma, G.P. \& A.S. Raghubanshi. 2009. Lantana invasion alter soil nitrogen pools and processes in the tropical dry deciduous forest of India. Applied Soil Ecology 42: 134-140.

Sharma, G.P., A.S. Raghubanshi \& J.S. Singh. 2005. Lantana invasion: an overview. Weed Biology and Management 5: 157-165.

Sharma O.P. 1988. How to combat Lantana (Lantana camara) menace- A current perspective. Journal of Scientific and Industrial Research 47: 611.

Sharma O.P. \& P.D. Sharma. 1989. Natural products of the Lantana plant - the present and prospects. Journal of Scientific and Industrial Research 48: 471-478.

Sharma O.P., H.P.S. Makkar, R.N. Pal \& S.S. Negi. 1980. Lantadene content and toxicity of the Lantana plants (Lantana camara L.) to guinea pigs. Toxicon 18: 485-480.

Sharma O.P., H.P.S. Makkar \& R.K. Dawra. 1988. A review of the noxious plant Lantana camara. Toxicon 26: 975-987.

Sharma, P.K. \& C.L. Acharya. 2000. Carry-over of residual soil moisture with mulching and conservation tillage practices for sowing of rainfed wheat (Triticum aestivum L.) in north-west India. Soil and Tillage Research 57: 43-52.

Sharma, P.K. \& D.K. Parmar. 1998. The effect of phosphorus and mulching on the efficiency of phosphorus use and productivity of wheat grown on a mountain Alfisol in the Western Himalayas. Soil Use and Management 14: 25-29. 
Sharma R.P. \& T.S. Verma. 2000. Effect of long term addition of Lantana biomass on crop yields and $\mathrm{N}$ uptake in rice-wheat cropping in Himalayan acid alfisols. Tropical Agriculture 77: 71-75.

Sharma, S. \& S.P. Singh. 1994. Energy use pattern and sustainable development: A case study in rural landscape of the Central Himalaya. Landscape and Urban Planning 29: 19-24.

Shaukat, S.S. \& I.A. Siddiqui. 2002. Allelopathic and antifungal potential of Lantana camara root leachates in soil. Pakistan Journal of Biological Science 5: 51-53.

Shimizu, Y. 1983. Phenological studies of the subtropical broad-leaved evergreen forests at Chichijima Island in the Bonin Islands. Japanese Journal of Ecology 33: 135-147.

Siddiqui, B.S., S.M. Raza, S. Begum \& S. Siddiqui. 1995. Pentacyclic triterpenoids from Lantana camara. Phytochemistry 38: 681-685.

Singh, J.S. \& S.P. Singh. 1987. Forest vegetation of the Himalaya. Botanical Review 53: 80-192.

Singh, J.S. \& S.P. Singh. 1992. Forests of Himalaya: Structure, Functioning and Impact of Man. Gyanodaya Prakashan, Nainital. 294 p.

Singh, S.K., V.J. Tripathi \& R.H. Singh. 1984. Triterpenoides of Lantana indica Roxb. (Verbenaceae). Indian Drugs 26: 395-400.

Singh, S.K., V.J. Tripathi \& R.H. Singh. 1990. 3ß, 24-Dihydroxyolean-12-en-28-olc acid-A pentacyclic triterpene acid from Lantana indica. Phytochemistry 29: 3360-3362.

Srivastava, A. \& S. Guleria. 2003. Evaluation of botanicals for mustard aphid, Lipaphis erysimi (Kalt.) control in Brassica. Himachal Journal of Agricultural Research. 29(1/2): 116-118.

Stone, B. C. 1970. The flora of Guam. Micronesica 6: 1-659.

Sundaram, B., A. Hiremath \& A. Prasad. 2018. Restoring Lantana camara invaded tropical deciduous forest: The response of native plant regeneration to two common Lantana removal practices. Indian Forester 144(6): 545-552.

Syed, Z. \& P.M. Guerin. 2004. Tsetse flies are attracted to the invasive plant Lantana camara. Journal of Insect Physiology 50: 43-50.

Thakur, M.L., M. Ahmad \& R.K. Thakur. 1992. Lantana weed (Lantana camara var. aculeata Linn.) and its possible management through natural insect pests in India. Indian Forester 118: 466-488.

Tilman, D., C.L. Lehman \& K.T. Thomas. 1997. Plant diversity and ecosystem productivity: Theoretical considerations. Proceedings of the National Acad. of Sciences 94: 1857-1861.

Tireman, H. 1916. Lantana in the forests of Coorg. Indian Forester 42: 384-392.

Troup, R.S. (1921). The Silviculture of Indian Tress. Vol. I-III. Clarendon Press, Oxford.

Vasudevan, P. \& S.K. Jain. 1991. Utilization of exotic weeds: an approach to control. In: Ramakrishnan P.S. (Ed.) Ecology of Biological Invasion in the Tropics. pp. 157-175. International Scientific Publishers, New Delhi, India.

Vats, S.K., R.P. Sood \& A. Gulati. 1994. Lantana camara L.- A lignocellulosic substrate for cultivation of Pleurotus sajor caju. Bioresource Technology 48: 49-52.

Ventataswamy, R., A. Doass, M. Sukumar \& H.M. Mubarack. 2010. Preliminary phytochemical screening and antimicrobial studies of Lantana indica Roxb. Indian Journal of Pharmaceutical Science 72: 229-231.

Verma, R.K. \& S.K. Verma. 2006. Phytochemical and termiticidal study of Lantana camara var. aculeata leaves. Fitoterapia 77: 466-468.

Vitousek, P.M., C.M. D’Antonio, L.L. Loope \& R. Westbrooks. 1996. Biological invasions as global environmental change. American Scientist 84: 218-228. 